\title{
PENYULUHAN PALAWIJA DESA RIDAN PERMAI UNTUK EKSISTENSI KEANEKARAGAMAN HAYATI SUMBER PANGAN
}

\author{
Ramdhan Witarsa ${ }^{1}$, Mufarizuddin ${ }^{2}$ \\ ${ }^{1)}$ Program Studi PGSD, Fakultas Ilmu Pendidikan, Universitas Pahlawan Tuanku Tambusai \\ e-mail: drdadan19@gmail.com \\ 2) Program Studi PGSD, Fakultas Ilmu Pendidikan, Universitas Pahlawan Tuanku Tambusai \\ e-mail: zuddin.unimed@gmail.com
}

\begin{abstract}
ABSTRAK
Desa Ridan Permai untuk Eksistensi Keanekaragaman Hayati Sumber Pangan ini secara spesifik bertempat di RT 003 RW 003 Desa Ridan Permai Kecamatan Bangkinang Kota, Kabupaten Kampar, Provinsi Riau. Sebagian besar masyarakat sasaran bekerja sebagai petani. Hal ini menggambarkan besarnya potensi masyarakat sasaran untuk terlibat dalam Penyuluhan Palawija untuk Eksistensi Keanekaragaman Hayati Sumber Pangan. Hal ini membuat kelompok tani Palawija ini menjawab tantangan akan terbengkalainya lingkungan lahan yang tidak produktif menjadi lebih produktif dan menjawab kebutuhan akan keanekaragaman hayati sumber pangan yang dapat memenuhi kebutuhan pasar/konsumen di Bangkinang Kota. Hal tersebut terbukti dengan banyaknya permintaan pasar tradisional Bangkinang Kota akan palawija, khususnya pare dan gambas. penanaman palawija ini juga memberikan dampak terhadap produktifnya lingkungan lahan dan eksistensi keanekaragaman hayati sumber pangan sekitar secara ekonomi dan tentu saja relevan dengan semua program kegiatan yang dilakukan oleh kelompok masyarakat sasaran.
\end{abstract}

Kata kunci: Penyuluhan, Palawija, Sumber Pangan

\section{ABSTRACT}

The village Ridan Permai for the Existence of the Biodiversity of the Food Source is specifically located in RT 003 RW 003 Desa Ridan Permai, Kecamatan Bangkinang City, Kampar Regency, Riau Province. The majority of the target community work as farmers. This illustrates the magnitude of the potential target communities to engage in Counseling Pulses to the Existence of Biodiversity of Food Sources. This makes the group of farmers Crops this answer the challenge will be the abandonment of land that is not productive to be more productive and answer the needs of the biodiversity of food sources that can meet the needs of the market/consumers in Bangkinang City. This is evident with the number of market demand traditional Bangkinang City will crops, especially bitter melon and squash. planting crops is also give impact on the productive environment of the land and the existence of biodiversity of food sources around in the economy and of course relevant to all program activities conducted by community groups target.

Keywords: Extension, Crops, Source of Food

\section{PENDAHULUAN}

Kelompok masyarakat sasaran pada Penyuluhan Palawija Desa Ridan Permai untuk Eksistensi Keanekaragaman Hayati Sumber Pangan ini secara spesifik bertempat di RT 003 RW 003 Desa Ridan Permai Kecamatan Bangkinang Kota, Kabupaten Kampar, Provinsi Riau. Kondisi masyarakat sasaran yang akan dilibatkan di RT 003 ini memiliki jumlah Kepala Keluarga (KK) sebanyak 30 KK dengan profil sebagai berikut: 
Tabel 1

Profil Desa Binaan

\begin{tabular}{|c|c|c|c|c|c|}
\hline \multirow[t]{2}{*}{ Jumlah KK } & \multirow{2}{*}{$\begin{array}{c}\text { Jumlah } \\
\text { Anggota } \\
\text { Keluarga }\end{array}$} & \multicolumn{2}{|c|}{ Jenis Kelamin } & \multicolumn{2}{|c|}{ Usia } \\
\hline & & Laki-laki & Perempuan & Produktif & $\begin{array}{c}\text { Non- } \\
\text { Produktif }\end{array}$ \\
\hline 30 & 120 & 40 & 80 & 66 & 54 \\
\hline \multicolumn{6}{|c|}{ Pekerjaan } \\
\hline Petani & IRT & Pedagang & Guru & PNS & Pensiunan \\
\hline 90 & 10 & 10 & - & - & - \\
\hline
\end{tabular}

Sumber: Buku Besar RT 003 RW 003 Desa Ridan Permai Kecamatan Bangkinang Kota

Berdasarkan Tabel 1 di atas, sebagian besar masyarakat sasaran bekerja sebagai petani. Hal ini menggambarkan besarnya potensi masyarakat sasaran untuk terlibat dalam Penyuluhan Palawija untuk Eksistensi Keanekaragaman Hayati Sumber Pangan. Selain itu, pada saat sosialisasi tentang penyuluhan ini, seluruh masyarakat antusias untuk terlibat didalamnya. Berdasarkan survei awal yang telah dilakukan oleh tim pengusul, berikut gambaran kondisi dan potensi wilayah yang didokumentasikan melalui foto-foto:

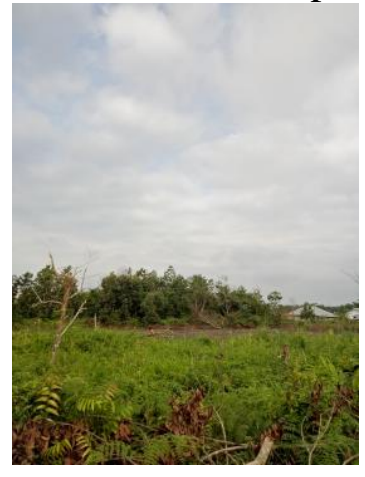

Gambar 1

Lingkungan/Lahan

Pertanian yang Sangat Luas dan Representatif

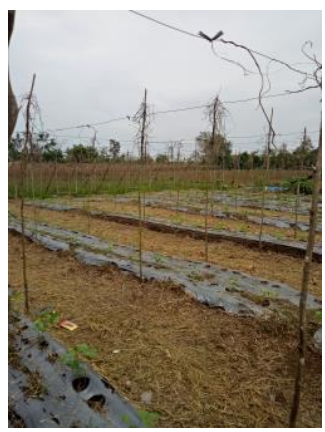

Gambar 4

Lokasi Lahan yang Akan diolah Kembali

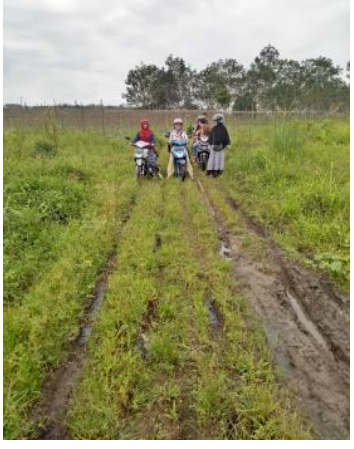

Gambar 2

Posisi Lahan yang Berada di Tengah-tengah Hutan Tidak Menyurutkan Tim untuk Tetap Semangat

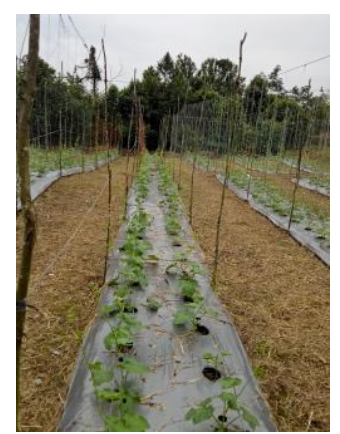

Gambar 5

Lahan yang Kembali Produktif (Harapan Tim

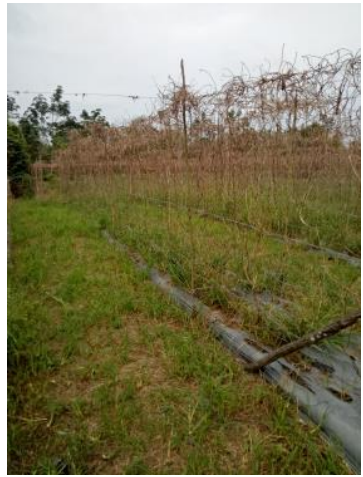

Gambar 3

Lokasi Lahan Palawija (Pare \& Gambas) yang Tertidur dan Perlu diolah Kembali

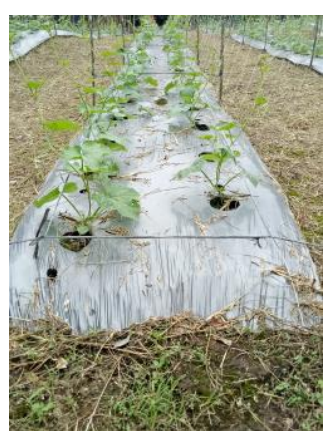

Gambar 6

Eksistensi Palawija (Pare \& Gambas) Terjaga melalui 
Apabila diperhatikan dari segi fisik, kelompok masyarakat sasaran sangat kekurangan dalam prasarana dan sarana penanaman palawija. Lingkungan lahan yang akan ditanam belum mempunyai sumber air sendiri, belum memiliki alat olah lahan seperti mesin pemotong rumput, mesin pompa air, hand traktor, dan alat semprot elektrik. Sementara lahan penanaman palawija tersebut sangat luas (1/2 hektar) dan sangat representatif untuk ditanami palawija. Palawija yang akan ditanam pada lahan ini adalah pare dan gambas.

Dari segi sosial, penanaman Palawija ini menjawab tantangan akan terbengkalainya lingkungan lahan yang tidak produktif menjadi lebih produktif dan menjawab kebutuhan akan keanekaragaman hayati sumber pangan yang dapat memenuhi kebutuhan pasar/konsumen di Bangkinang Kota. Hal tersebut terbukti dengan banyaknya permintaan pasar tradisional Bangkinang Kota akan palawija, khususnya pare dan gambas.

Dari segi ekonomi, penanaman palawija ini juga memberikan dampak terhadap produktifnya lingkungan lahan dan eksistensi keanekaragaman hayati sumber pangan sekitar secara ekonomi dan tentu saja relevan dengan semua program kegiatan yang dilakukan oleh kelompok masyarakat sasaran. Berdasarkan hasil survei awal yang telah dilakukan tim pengusul, terdapat beberapa potensi desa yang bisa dikembangkan (palawija dan karet). Namun kami tim pengusul memilih palawija dikarenakan sangat mendesaknya lingkungan lahan yang harus diolah, perlunya masyarakat sasaran diberdayakan, dan kurangnya penanaman palawija untuk eksistensi keanekaragaman hayati sumber pangan di Desa tersebut.

\section{METODE}

Adapun metode pelaksanaan program ini adalah metode penelitian dan pengembangan. Data-data yang dikumpulkan berupa data-data kuantitatif dan kualitatif. Tahapan-tahapan yang dilakukan sebagai berikut: survei awal, membuat draft program, penyuluhan penanaman Palawija (Pare dan Gambas) melalui sistem Padat Karya dan pendampingan berkelanjutan, uji coba terbatas, pengujian, program penanaman Palawija (pare dan gambas) melalui sistem padat karya dan pendampingan berkelanjutan yang telah teruji.

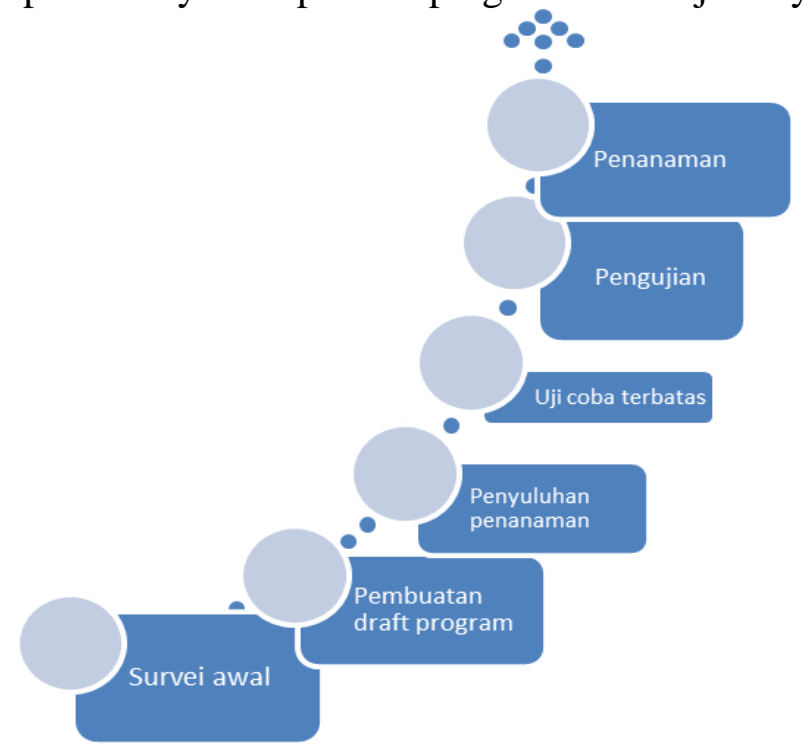

Gambar 3.1

Metode Pelaksanaan 


\section{HASIL DAN PEMBAHASAN}

Solusi dan indikator-indikator keberhasilan program yang diharapkan sebagai berikut:

1. Adanya perubahan perilaku masyarakat (bertambahnya pengetahuan, sikap mental, mindset, dan keterampilan) sesudah dilakukannya Penyuluhan Penanaman Palawija (Pare dan Gambas) di Desa Ridan Permai melalui Sistem Padat Karya dan Pendampingan Berkelanjutan. Melalui sistem padat karya dan pendampingan berkelanjutan tersebut, diharapkan perubahan-perubahan (pengetahuan, sikap mental, mindset, dan keterampilan) tersebut terus tampak pasca penyuluhan.

2. Adanya perubahan-perubahan fisik pasca penyuluhan, seperti lingkungan lahan yang lebih produktif, serta peralatan penanaman yang menunjang. Perubahan-perubahan fisik tersebut diukur melalui daftar ceklis.

3. Adanya MoU-MoU dengan berbagai mitra: a. MoU dengan Penyedia Benih Palawija (untuk menjamin pasokan benih palawija); b. MoU dengan Desa Mitra (sebagai Desa Binaan); c. MoU dengan pengelola pasar tradisonal Bangkinang Kota (sebagai pasar/konsumen tetap) pasca penyuluhan.

4. Terbentuknya Palawija Center sebagai lembaga lokal di masyarakat sebagai Pembina petani baru yang ingin menjadi pengusaha palawija; Terbentuknya Palawija DRP (Desan Ridan Permai) sebagai pelanjut program yang bergerak dalam bidang distribusi sebagai awal berdirinya Pusat Distribusi Palawija; Program pasca Penyuluhan: Rumah Palawija yang menyediakan berbagai macam jenis palawija yang dibutuhkan pasar dan masyarakat umum dengan harga yang wajar dan menguntungkan petani.

Target-target luaran yang diharapkan sebagai berikut:

1. Panduan-panduan penanaman palawija (pare dan gambas) lengkap dengan berbagai teknik mengolah lahan menjadi lebih produktif.

2. Poster, publikasi hasil pelaksanaan program, dan MoU-MoU dengan pihak-pihak terkait.

\section{SIMPULAN}

Manfaat-manfaat yang akan diperoleh masyarakat sasaran dan pihak-pihak terkait:

1. Bertambahnya pengetahuan, sikap mental, mindset, dan keterampilan masyarakat sasaran dalam menanam palawija (pare dan gambas) yang baik secara kualitas maupun kuantitas.

2. Lahan-lahan yang lebih produktif dan terstandar, serta peralatan penanaman yang menunjang guna keberlanjutan keanekaragaman hayati sumber pangan.

3. Adanya perhatian Penyedia Benih Palawija untuk menjamin pasokan bahan benih palawija, adanya perhatian Pemerintah Kabupaten Kampar dan Provinsi Riau terhadap Desa Ridan Permai sebagai Desa Binaan baik perhatian moril dan fisik; Adanya perhatian Pengelola-pengelola Pasar Tradisonal maupun Modern sebagai konsumen tetap produk Palawija (pare dan gambas) Desa Ridan Permai pasca Penyuluhan.

4. Semakin dikenalnya Palawija Center sebagai lembaga lokal di masyarakat sebagai Pembina petani-petani baru yang ingin menjadi pengusaha Palawija; semakin dikenalnya Palawija DRP sebagai pelanjut program yang bergerak dalam bidang distribusi sebagai awal berdirinya Rumah Palawija.

\section{SARAN}

Diharapkan kedepannya pengabdian masyrakat ini dapat membentuk Palawija Center sebagai lembaga lokal di masyarakat sebagai Pembina petani baru yang ingin menjadi pengusaha palawija; Terbentuknya Palawija DRP (Desan Ridan Permai) sebagai pelanjut program yang bergerak dalam bidang distribusi sebagai awal berdirinya Pusat Distribusi 
Palawija; Program pasca Penyuluhan: Rumah Palawija yang menyediakan berbagai macam jenis palawija yang dibutuhkan pasar dan masyarakat umum dengan harga yang wajar dan menguntungkan petani.

\section{UCAPAN TERIMA KASIH}

Penulis mengucapkan terimaksih kepada Universitas Pahlawan Tuanku Tambusai yang telah memberikan dukungan kegiatan pengabdian masyarakat ini dan tidak lupa juga peniliti mengucapakn terimakasih kepada kepala desa permai dan kelompok tani desa ridan permai khususnya kelompok tani palawija Desa Ridan Permai.

\section{DAFTAR PUSTAKA}

Peraturan Pemerintah Nomor 12 tahun 2010 tentang Penelitian dan Pengembangan serta Pendidikan dan Pelatihan.

Peraturan Menteri Kehutanan Nomor: P. 29/Menhut-II/2013 tentang Pedoman Pendampingan Kegiatan Pembangunan.

Hasibuan, M.SP. (2010). Manajemen Sumber Daya Manusia. PT. Bumi Aksara: Jakarta.

Suharsimi. (2011). Prosedur Penelitian. Rhineka Cipta: Jakarta.

Wursanto. (2009). Manajemen Kepegawaian 1. Penerbit Kanisius: Jogyakarta.

Armstrong, M. (2006). A Handbook of Human Resource Management Practice (10th

Edition). London: Kogan Page. 